\title{
VII. LEPIDOPTERA.
}

\author{
By A. G. Butler.
}

The Lepidoptera obtained in Christmas Island were unfortunately placed in a store-box with a large piece of camphor, which got loose during the transmission of the collection to England, and utterly destroyed all the specimens with the exception of three; the latter are a good deal injured, but two of them are in sufficiently good condition for determination.

Among the fragments of wings I am also able to recognize what was doubtless a female Hypolimnas, apparently $H$. proserpina, Cram., a species occurring in Java. The two Butterflies which escaped destruction are well-marked new species.

VADEBRa MaCleari, sp. $\mathrm{n}$.

Allied to $\boldsymbol{V}$. sepulchralis of Java, but of a deep pitchy-brown colour, the wings almost black in the centre; the secondaries with a broad snow-white external band from anal angle to radial rein, whence it becomes suffused with greyish brown to apex; indications

Fig. 4.

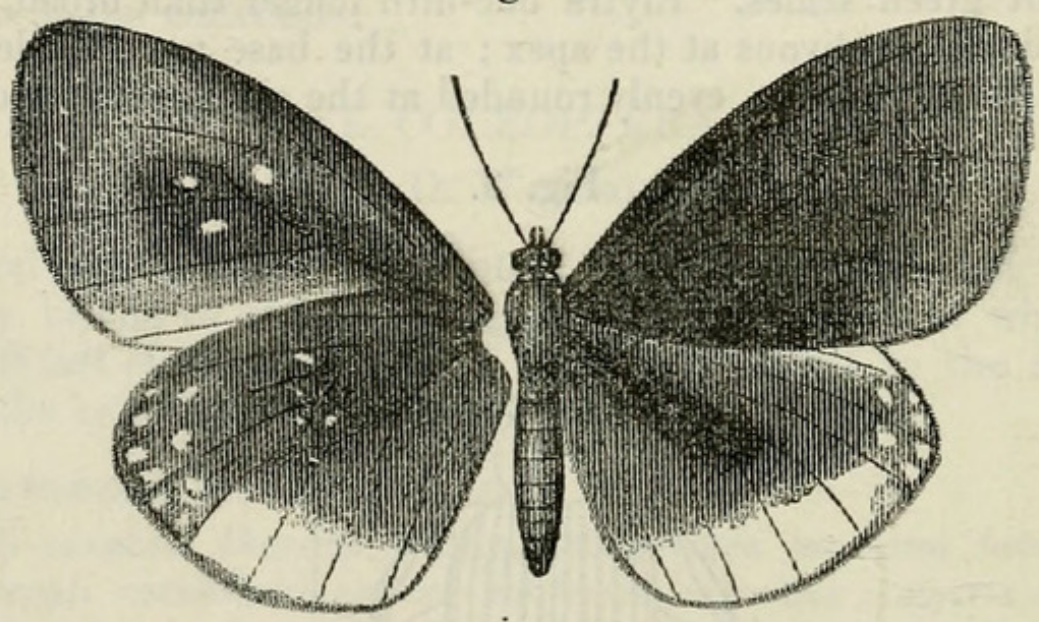

Vadebra macleari.

of three white spots in the form of a triangle on the radial and subcostal interspaces towards outer margin; a narrow brown border with black fringe tapering from apex to second median branch, remainder of fringe blackish; costal area greyish white; body quite normal, excepting that the white spots on the thorax are very smail. Wings below chocolate-brown, the primaries with the central area blackish and the internal area whitish; a bluish-white spot in the cell ard two on the basal half of the median interspaces as in $V$. sepulchralis; secondaries with a small spot in the cell and an angular series of five or six beyond the cell; white external area as above, with three subapical and seven submarginal brown-edged pearly white spots. Expanse of wings 79 millim.

There were originally five specimens of this fine species, but of four of them only fragments of the wings remain. 
Terias amplexa, sp. $n$.

Perhaps nearest to $T$. desjardinsi of Madagascar, but very distinct from all described species; wings above bright gamboge or lemon-yellow; primaries with black costal margin and a perfectly regular, rather narrow, external border of almost equal width throughout and regularly sinuated between each pair of nervures; secondaries with a narrower border formed by the union of a series

Fig. 5 .

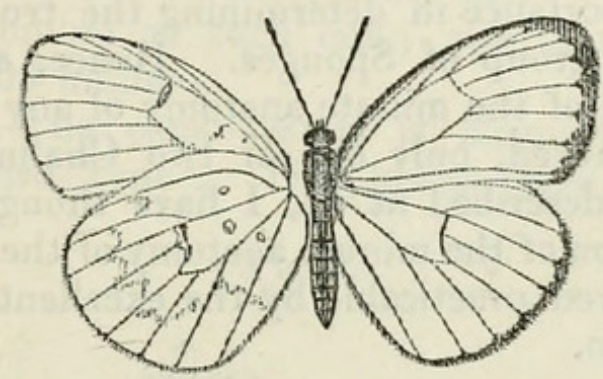

Terias amplexa.

of marginal spots, the inner edges of which are bracket-shaped, $\sim$. Body quite normal; under surface bright sulphur-yellow, with marginal black dots and indistinct brown markings, as in $T$. hecabeoides; no subapical brown patch on the primaries as in $T$. desjardinsi. Expanse of wings 42 millim.

One male example.

In colouring this species corresponds better with $T$. moorei from Camorta than with $T$. desjardinsi; but the regularity of the border to the primaries separates it at a glance from all the described forms of this group.

The Moth is much injured; it is a small insect approaching Pyralis miseralis, Walk., but is too much broken and rubbed to enable one to say whether or not it is an undescribed species.

\section{ECHINODERMATA.}

\section{By F. J. BeLL.}

The Echinoderms are common Indo-Pacific species: viz. Linckia diplax (M. Tr.), Ophiocoma athiops (Ltk.), Ophiocoma scolopendrina (Ag.), Actinopyga miliaris. A specimen of Actinometra is unfortunately too much injured to allow of description, but undoubtedly belongs to an undescribed species, distinguished by the large number of cirri; cirri, as a rule, being numerous in Antedon and scanty in Actinometra. 


\section{$2 \mathrm{BHL}$ Biodiversity Heritage Library}

Butler, Arthur G. 1887. "VII. LEPIDOPTERA." Proceedings of the Zoological Society of London 1887, 522-523.

https://doi.org/10.1111/j.1096-3642.1887.tb03005.x.

View This Item Online: https://www.biodiversitylibrary.org/item/99199

DOI: https://doi.org/10.1111/j.1096-3642.1887.tb03005.x

Permalink: https://www.biodiversitylibrary.org/partpdf/73027.

\section{Holding Institution}

Natural History Museum Library, London

\section{Sponsored by}

Natural History Museum Library, London

\section{Copyright \& Reuse}

Copyright Status: Public domain. The BHL considers that this work is no longer under copyright protection.

This document was created from content at the Biodiversity Heritage Library, the world's largest open access digital library for biodiversity literature and archives. Visit BHL at https://www.biodiversitylibrary.org. 